\title{
PELAKSANAAN TIMBANG TERIMA KEPERAWATAN TERHADAP KEPUASAN KERJA PERAWAT
}

\author{
Ganda Perwirah, Yanti Sutriyanti, Surani Warsito \\ Politeknik Kesehatan Kementerian Kesehatan Bengkulu, Prodi Keperawatan Curup \\ Jalan Indragiri No.03 Padang Harapan Kota Bengkulu \\ qinan_fikri@yahoo.co.id
}

\begin{abstract}
Hand over nursing is a way to convey and receive information related with a client's condition, so that the service to be provided can be justified as well as to give satisfaction to the work performed. This study aimed to determine the relathionship between the implementation nursing hand over the job satisfaction of nurses in hospital curup 2014. The study design used is descriptive method with cross sectional approach. Analytical samples are 79 nurses and sampling with purposive sampling proportional amples taken in each room inpatients Curup hospital. Univariate analysis $(94,9 \%)$ of nurses carrying out over hand receive and $(44,1 \%)$ lower nurse job satisfaction. The results of the analysis with known statistical test Chi Square P value $=0,625>\alpha 0.05$; CI 9,5\% there is no relathionship between implementation hand over accept the job satisfaction of nurses. Indicators of job satisfaction not only in the execution of the work, while the other factors that affect is a psychological factor, colleagues, promotion, and sallary / wages.
\end{abstract}

Keywords : hand over, job satisfaction nurse.

\begin{abstract}
Abstrak : Timbang terima keperawatan merupakan cara untuk menyampaikan dan menerima informasi berkaitan dengan kondisi klien, agar pelayanan keperawatan yang akan diberikan terencana dengan jelas dan berkesinambungan secara komprehensif sehingga sebagai perawat kelolaan dapat melaksanakan kinerja asuhan keperawatan dengan baik. Tujuan penelitian ini untuk mengetahui hubungan antara pelaksanaan timbang terima keperawatan dengan kepuasan kerja perawat di RSUD Curup. Desain penelitian yang di gunakan adalah deskriptif Analitik dengan pendekatan Cross Sectional . Sampel penelitian ini sebanyak 79 perawat yang bekerja di ruang rawat inap keperawatan. Pengambilan sampe lpenelitian menggunakan purposive sampling yang diambil secara proporsional di setiap ruangan rawat inap RSUD Curup. Penelitian ini menunujukkan hampir seluruh $(94,9 \%)$ perawat melaksanakan timbang terima dengan baik dan hampir sebagian $(44,1 \%)$ kepuasan kerja perawat tinggi dengan uji statistik didapatkan nilai $\mathrm{p}=0,625>\alpha 0,05$; CI 9,5\% berarti tidak ada hubungan antara pelaksanaan timbang terima keperawatan dengan kepuasan kerja perawat. Kepuasan kerja tidak hanya dipengaruhi oleh pelaksanaan kinerja perawat sebelum melaksanakan asuhan keperawatan, tetapi ada faktor lain yang dapat mempengaruhi kepuasan perawat dalam bekerja meliputi faktor psikologis, teman sekerja, promosi, dan gaji/upah.
\end{abstract}

Kata kunci : Timbang Terima, Kepuasan Kerja Perawat.

Pengoptimalan peran dan fungsi perawat, terutama peran dan fungsi mandiri merupakan satu upaya dalam meningkatkan profesionalisme pelayanan keperawatan. Hal ini berkaitan dengan tuntutan profesi dan tuntutan global bahwa setiap perkembangan dan perubahan memerlukan pengelolaan secara profesional dengan memperhatikan setiap perubahan yang terjadi. Tuntutan masyarakat terhadap kualitas pelayanan dirasakan sebagai suatu fenomena yang harus direspon oleh perawat.
Respon yang ada harus bersifat kondusif dengan belajar tentang konsep pelayanan keperawatan dan langkah- langkah konkret dalam pelaksanaannya. Langkah- langkah tersebut dapat berupa penataan ketenagaan dan pasien, penerapan MAKP dan perbaikan dokumentasi keperawatan (Sitorus 2006 dalam Hasibuan 2007).

Tuntutan masyarakat terhadap pelayanan yang berkualitas merupakan masukan bagi pemberi pelayanan yang harus direspon bila 
ingin tetap bertahan.Bersamaan dengan hal tersebut di atas, kebijakan pasar bebas menciptakan iklim kompetisi terhadap pelayanan kesehatan yang diadakan Rumahsakit (RS) baru dengan berorientasi pada kepuasan klien yang menjadi tujuan penggunaan jasa pelayanan RS (Dep.Kes, 2000).

Pelayanan keperawatan memegang peranan penting karena di perlukan selama 24 jam dalam memenuhi kebutuhan dasar pasien yang terganggu karena sakit, pengelolaan asuhan keperawatan di setiap unit ruang di Rumah Sakit merupakan gambaran kinerja di unit tersebut, komponennya terdiri dari perawat, sistem pemberian asuhan keperawatan, sarana prasarana serta dokumentasi asuhan keperawatan. Agar hal tersebut diatas dapat diterapkan perlu dilaksanakan kegiatan peningkatan kemampuan teknis perawat dan pemberian pelayanan keperawatan profesional di Rumah Sakit (Dit bina Yankep,2010).

Profesionalisme dalam pelayanan keperawatan dapat dicapai dengan mengoptimalkan peran dan fungsi perawat, terutama peran dan fungsi mandiri perawat. Hal ini dapat diwujudkan dengan baik melalui komunikasi yang efektif antar perawat, maupun dengan tim kesehatan yang lain. Salah satu bentuk komunikasi yang harus ditingkatkan efektifitasnya adalah saat pergantian shift, yaitu saat timbang terima klien. Timbang terima merupakan teknik atau cara untuk menyampaikan dan menerima sesuatu (informasi) yang berkaitan dengan keadaan klien. Timbang terima klien harus dilakukan seefektif mungkin dengan menjelaskan secara singkat jelas dan lengkap tentang tindakan mandiri perawat, tindakan kolaboratif yang sudah dilakukan/belum dan perkembangan klien saat itu. Informasi yang disampaikan harus akurat sehingga kesinambungan asuhan keperawatan dapat berjalan dengan sempurna. Timbang terima dilakukan oleh perawat primer antar shift secara tulisan dan lisan (Nursalam, 2002).

Keakuratan data yang diberikan saat timbang terima sangat penting, karena dengan timbang terima ini maka pelayanan asuhan keperawatan yang diberikan akan bisa dilaksanakan secara berkelanjutan, dan mewujudkan tanggung jawab dan tanggung gugat dari seorang perawat. Bila timbang terima tidak dilakukan dengan baik, maka akan muncul kerancuan dari tindakan keperawatan yang diberikan karena tidak adanya informasi yang bisa digunakan sebagai dasar pemberian tindakan keperawatan. Hal ini akan menurunkan kualitas pelayanan keperawatan dan menurunkan tingkat kepuasan pasien. Kegiatan timbang terima yang telah dilakukan perlu dipertahankan dan ditingkatkan kualitasnya (Nursalam, 2002).

Jumlah perawat yang bekerja di RSUD Curup berjumlah 132 Orang perawat dari keseluruhan ruangan, yaitu di Ruang Mawar (anak) perawat 22 orang PNS 10 TKS 12 , Ruang Kebidanan (Teratai) 23 PNS 17 TKS 6 , Ruang Interne perawat 21 orang PNS 12 TKS 9, Ruang Raflesia perawat 22 orang PNS 9 TKS 13, Ruang ICU perawat 25 orang PNS 14 TKS 11, Ruang Bedah perawat 19 orang PNS 10 TKS 9 (Bidang Ketenagaan RSUD Curup, 2013).

Timbang terima atau over hand selama ini sudah dilakukan di Rumah Sakit Daerah Curup (RSUD Curup) dengan observasi di tiga ruangan di RSUD Curup yaitu Ruang Rawat Inap Penyakit Dalam, Ruang Raflesia, dan Ruang Bedah. Isi dan substansi timbang terima yang dilakukan selama ini adalah identitas pasien, diagnosa medis, tindakan keperawatam, program terapi yang sudah dilakukan dan rencana tindakan yang akan dilakukan . Timbang terima yang dilakukan di RSUD Curup dilakukan secara lisan yaitu dilakukan di nurse station dan tertulis pada buku laporan keperawatan kemudian keliling ke semua pasien. Timbang terima perlu terus ditingkatkan di RSUD Curup Kabupaten Rejang Lebong baik teknik maupun alurnya karena timbang terima merupakan bagian penting dalam menginformasikan permasalahan klien sehari-hari.

\section{BAHAN DAN CARA KERJA}

Desain penelitian yang di gunakan adalah metode deskriptif analitik dengan pendekatan potong lintang karena bertujuan untuk melihat hubungan dua variabel (Noto- 
admodjo, 2005). populasi dalam penelitian ini adalah perawat yang bekerja di ruang rawat inap Rumah SakitUmum Daerah Curup yang sudah berstatus sebagai PNS/Perawat yang sudah bekerja selama 2 tahun yang berjumlah 132 perawat. Besar sampel penelitian ini diambil adalah 79 perawat.

Cara pengambilan sampel disetiap ruangan diambil secara Proporsional berdasarkan besarnya jumlah perawat di setiap ruangan, sedangkan pengambilan sampel terhadap responden diambil secara Purposive Sampling dengan keten-tuan : (1) responden merupakan Pegawai Negeri Sipil (PNS), (2) Responden memi-liki pengalaman kerja di RSUD Curup minimal 2 tahun .

\section{HASIL}

\section{Analisa Univariat}

Tabel. 1 Distribusi Frekuensi Responden Berdasarkan Pelaksanaan Timbang Terima Keperawatan

\begin{tabular}{lcc}
\hline \multicolumn{1}{c}{ Variabel } & Frekuensi & $\begin{array}{c}\text { Persentase } \\
(\mathbf{1 0 0 \% )}\end{array}$ \\
\hline Timbang Terima & & \\
Baik & 76 & 94,9 \\
Kurang & 4 & 5,1 \\
Kepuasan Kerja & & \\
Tinggi & 35 & 44,30 \\
Rendah & 44 & 55,69 \\
\hline
\end{tabular}

Berdasarkan tabel 1.diatas menunjukkan bahwa sebagian besar $(96,20 \%)$ responden menyatakan timbang terima keperawatan baik, dan sebagian $(3,79 \%)$ menyatakan kurang. Dan hampir sebagian besar $(44,30 \%)$ responden menyatakan kepuasan kerjanya tinggi, dan sebagian $(55,69 \%)$ menyatakan kepuasan kerjanya kurang.

\section{Analisa Bivariat}

Tabel 3 Hubungan Pelaksanaan Timbang Terima Keperawatan Dengan Kepuasan Kerja Perawat

\begin{tabular}{|c|c|c|c|c|c|c|c|}
\hline \multirow{3}{*}{$\begin{array}{c}\text { Timbang } \\
\text { Terima }\end{array}$} & \multicolumn{4}{|c|}{$\begin{array}{c}\text { Kepuasan Kerja } \\
\text { Perawat }\end{array}$} & \multicolumn{2}{|c|}{ Total } & \multirow{3}{*}{$\begin{array}{c}\mathbf{P} \\
\text { Value }\end{array}$} \\
\hline & \multicolumn{2}{|c|}{ Tinggi } & \multicolumn{2}{|c|}{ Rendah } & \multirow{2}{*}{$\mathbf{n}$} & \multirow{2}{*}{$\%$} & \\
\hline & $\mathbf{n}$ & $\%$ & n & $\%$ & & & \\
\hline Baik & 41 & 54,7 & 34 & 45,3 & 75 & 100 & 0,625 \\
\hline Kurang & 3 & 75,0 & 1 & 25,0 & 4 & 100 & \\
\hline
\end{tabular}

Berdasarkan tabel 3. diatas, diperoleh bahwa responden yang melakukan timbang terima keperawatan baik baik dan juga melakukan timbang terima kurang sebagian besar memiliki kepuasan kerja rendah. Hasil analisis dengan menggunakan uji statistik $C h i$ Square diketahui nilai $\mathrm{p}=0,625>\alpha=0,05$, berarti tidak terdapat hubungan yang signifikan antara pelaksanaan timbang terima keperawatan dengan kepuasan kerja perawat di RSUD Curup.

\section{PEMBAHASAN}

Dari hasil penelitian tersebut tidak terdapat hubungan yang signifikan antara pelaksanaan timbang terima keperawatan dengan kepuasan kerjaperawat di Ruang Rawat Inap RSUD Curup tahun 2014.

Hasil penelitian ini berbeda dengan pendapat Yasir (2012) yang menyatakan adanya hubungan antara pelaksanaan timbang terima keperawatan dengan kinerja perawat. Costello (1994) dalam wibowo (2010), sebelumnya berpandangan bahwa timbang terima keperawatan merupakan bagian yang memberikan kontribusi dalam melakukan asuhan keperawatan manajemen kinerja merupakan kekuatan dasar pendorong yang berada dibelakang semua keputusan operan , usaha kerja, kepuasan kerja, dan alokasi sumberdaya dalam timbang terima.

Dalam Hasibuan (2007) menyatakan bahwa kepuasan tidak hanya di pengaruhi oleh faktor pekerjaan ,tetapi ada beberapa faktor lain yaitu faktor psikologis, faktor sosial, faktor fisik, dan faktor finansial. Pada Levi (2002) ada lima aspek kepuasan kerja, yaitu pekerjaan itu sendiri, teman sekerja, promosi, dan gaji/upah. Perbedaan hasil penelitian dengan peneliti - peneliti lainnya, dikarenakan penelitian sejenis sebelumnya hanya membahas pelaksanaan timbang terima keperawatan dengan kinerja perawat serta responden pada penelitian sebelumnya hanya focus dengan responden pasien, berbeda dengan penelitian saya yang langsung mengambil responden perawat senior di rumahsakit yang memiliki pengalaman kerja minimal 2 tahun atau perawat yang telah berstatus PNS. Penelitian yang telah dibuat oleh peneliti perlu dikaji lebih dalam instrument yang dibuat perlu di evaluasi dan pengecekan yang berkelanjutan 
untuk memperbaiki validitas dan reabilitasnya.Sampel yang digunakan peneliti kecil, sehingga hasil pengukuran terhadap sampel kurang representatif untuk populasi seluruhnya jika kita bandingkan dengan penelitian yang populasinya lebih besar.Ditunjang dari hasil penelitian pelaksanaan timbang terima keperawatan di RSUD Curup sudah dilaksanakan dengan baik dengan persentase yang besar. Hal ini menggambarkan bahwa pelaksanaan timbang terima keperawatan di RSUD Curup sudah berjalan dengan baik.

\section{KESIMPULAN}

Dari hasil penelitian yang berjudul hubungan pelaksanaan timbang terima keperawatan dengan kepuasan kerja perawat di RSUD Curup, disimpulkan bahwa hampir

\section{DAFTAR RUJUKAN}

Arikunto, Suhasimi. (2007). Manajemen Penelitian.Jakarta : Rhineka Cipta.

Byars, L.L., and L. W., Rue (2005). Human Resources Management, McGraw-Hill, New York dalam Hasibuan (2007).

DitBinaYankep.(2010). Peningkatan Kemampuan Teknis Perawat Dalam System Pemberian Pelayanan Keperawatan Profesional Di Rumah Sakit, Jakarta Kementerian Kesehatan RI.

Handoko, T Hani. (2003). Manajeme npersonalia dan Sumber Daya Manusia. BPFE,Yogyakarta.

Hasibuan, M. ( 2007). Manajemen Sumber Daya Manusia, BumiAksara, Indonesia Jakarta.

Kinicki, Angelo and R. Kreitner (2005). Organizational Behavior Key concepts skills and best Practice, McGraw-Hill, New York dalam Hasibuan (2007).

Larasati, N. (2006). Analisa Kebutuhan Tenaga Keperawatan Di RumahSakit. Diunduh dari http://nabilayudhityalarasati .com. seluruh responden melaksanakan timbang terima keperawatan dengan baik. Sebagian besar responden menyatakan kepuasan kerja perawa trendah.Tidak ada hubungan yang signifikan antara pelaksanaan timbang terima keperawatan dengan kepuasan kerja perawat. Kepuasan tidak hanya dipengaruhi oleh pekerjaan itu sendiri, tapi ada banyak faktor lain yang dapat mempengaruhi kepuasan kerja perawat, diantaranya ada faktor psikologis, sosial, fisik dan finansial. Bagi institusi rumah sakit guna meningkatkan kepuasan kerja perawat diharapkan tidak hanya menilai pekerjaan perawat, akan tetapi dapat meningkatkan reward penghargaan dan tunjangan serta apresiasi bagi perawat yang berprestasi dan kompeten.

Luthans, F. (2005).Organizational Behavior, McGrawHill Book Co-Singapore, Singapura dalam Hasibuan (2007).

Nursalam. (2001). Proses \& Dokumentasi Keperawatan Konsep \& Praktik. Jakarta: Salemba Medika.

Nelson, D.L., and J.C., Quick. (2006). Organizatonal Behavior Foundations Realities and Challenges, Thompson South Western, United States of America dalam Hasibuan (2007).

Notoatmodjo (2005) Metode Penelitian Kesehatan. Edisi Revisi, Rineka Cipta ; Jakarta

Rivai, (2003). Manajemen Kinerja. Jakarta: Raja Wali Press

Robbins, S.P., and T.A., Judge. (2009). Organizational Behavior, Pearson Prentice Hall, United State Of America, New York.

RSUD Curup.(2013). Data Kepegawaian RSUD Curup.

Swansburg, R.C. \&Swansburg, R.J. (1999) .Introductory management and leadership fornurses.Canada : Jones and Barlett Publishers. Diakses tanggal 28 Februari 2014 dari www.book.com. 